\title{
FAKTOR-FAKTOR YANG MENYEBABKAN PELANGGARAN HAM DI YAMAN PADA MASA PEMERINTAHAN ALI ABDULLAH SALEH
}

\author{
Shinta Bella Maulidya Firdaus \\ Universitas Teknologi Yogyakarta \\ shintabellamf@gmail.com
}

\begin{abstract}
ABSTRAK
Yaman merupakan suatu negara di daratan Timur Tengah yang mengalami konflik bersaudara hingga menyebabkan pelanggaran HAM. Keadaan pemerintahan yang otoriter serta kondisi perpolitikan yang begitu kacau membuat banyak sekali konflik yang melibatkan masyarakat sipil dengan pemerintah. Hal ini membuat banyak masyarakat sipil yang akhirnya membentuk suatu kelompok oposisi dalam melawan kediktatoran pemerintah terhadap rakyatnya yaitu Houthi. Kelompok oposisi ini terus melawan pemerintah Ali Abdullah Saleh hingga mengakibatkan banyak demonstrasi dan kericuhan konflik yang berakhir pada pelanggaran HAM. Kondisi ini semakin buruk, ketika konflik internal sudah menjadi internasional yaitu masuknya negara lain yang ikut campur dalam krisis konflik di Yaman. Salah satunya ialah Arab Saudi dan Amerika Serikat. Penelitian ini dilakukan dengan menggunakan pendekatan kualitatif deskriptif untuk bisa menjelaskan kondisi konflik secara jelas dan terperinci. Teori dan konsep yang digunakan meliputi konsep konflik untuk bisa mengidentifikasi jenis konflik apa yang sedang terjadi di Yaman. Konsep HAM merupakan konsep yang menjelaskan dampak dari adanya konflik yang terjadi yaitu pelanggaran HAM, dan teori yang mendukung dalam penelitian ini adalah Hukum Humaniter suatu hukum perang dengan berbagai aturan perang serta siapa saja yang perlu bertanggung jawab dan siapa yang harus dilindungi.
\end{abstract}

Kata Kunci : HAM; Houthi; Yaman, Intervensi Arab Saudi dan Amerika Serikat

\begin{abstract}
Yemen is a country on the mainland of the Middle East that is experiencing civil conflict that has caused human rights violations. The authoritarian state of government and the chaotic political conditions created a lot of conflicts involving civil society and the government. This led many civil society to form an opposition group against the government dictatorship against the people, namely the Houthis. This opposition group continued to fight against Ali Abdullah Saleh's government, resulting in many demonstrations and conflict chaos which ended in human rights violations. This condition is getting worse, when the internal conflict has become international, namely the entry of other countries that have interfered in the conflict crisis in Yemen. One of them is Saudi Arabia and the United States. This research was conducted using a descriptive qualitative approach to explain the conflict conditions clearly and in detail. The theories and concepts used include the concept of conflict in order to identify what kind of conflict is happening in Yemen. The concept of human rights is a concept that explains the impact of conflicts that occur, namely human rights violations, and the theory that supports this research is humanitarian law, a law of war with various rules of war and who needs to be responsible and who should be protected.
\end{abstract}

Keywords : Human Right; Houthis; Yemen, Saudi Arabia and the United States intervention 


\section{PENDAHULUAN}

Konflik di Yaman merupakan konflik internal yang terjadi dengan adanya suatu pergesekan antara pemerintah yang otoriter dengan masyarakat sipil Yaman. Salah satu yang memotivasi munculnya konflik di Yaman adalah fenomena Arab Spring dimana berfokus pada usaha masyarakat sipil untuk menggulingkan rezim di kawasan Timur Tengah saat itu di akhir tahun 2010 (Jediza, 2017:1). Tidak terkecuali dengan Yaman yang merupakan negara dengan pemimpin yang otoriter.

Saat Ali Abdullah Saleh memimpin begitu banyak peristiwa yang meresahkan masyarakat Yaman seperti tindakan korupsi, kemiskinan, perselisihan ekonomi, dan yang paling dominan adalah kesenjangan sosial. Saleh memiliki cara untuk menyuap para pemimpin militer daerah dan pemerintahan untuk kepentingan dirinya. Sikapnya ini duduga karena memiliki hubungan dekat dengan pemerintah Amerika Serikat dan kaum Wahabi-Salafisme yaitu kelompok penentang komunitas lokal dan tradisional (Ghafur, 2015:127). Data dari PBB menyebutkan Ali Abdullah Saleh menyimpan kekayaan asetnya dari hasil korupsi sebesar 32-60 miliar US Dollar (Aljazeera, 2015). Dalam bidang kemiskinan, Yaman menempati negara keempat termiskin dalam Human Development Index (HRD UNDP, 2015), di Jazirah Arab dengan rata-rata perkapita pertahun sebesar 800 US Dollar (Ghafur, 2015:120). Terbukti angka pengangguran yang cukup tinggi hingga mencapai lebih dari 40 persen (GG, 2017). Hal inilah yang melahirkan adanya konflik sosial di masyarakat melalui gerakan separatisme (Jediza, 2017:2-3). Pemberontakan terjadi terus-menerus hingga jatuhnya para demonstran menjadi korban melawan militer di negaranya sendiri. Peristiwa ini dilakukan oleh Saleh bagi siapapun yang berani menentang segala kebijakannya maka akan segera dibasmi atau dilenyapkan. Meskipun konflik yang terjadi dikarenakan adanya konflik sosial antara pemerintah dengan masyarakat sipil berlangsung hingga menyebabkan korban berjatuhan, akan tetapi rezim pemerintah di bawah Pimpinan Saleh masih terus dijalankan (Merliani, 2019:26).

Yaman dalam masa pemerintahan Saleh terus mengalami pergolakan yang membuat keadaan perang semakin sengit. Konflik semakin rumit setelah kemunculan dari para pemberontak yang menentang kepemimpinan Saleh. Kelompok ini disebut dengan Houthi. Houthi merupakan pemberontak yang beraliran Syiah (Maulana, 2018:106). Awal mula pergerakan hanya mengkaji masalah keagamaan, akan tetapi kelompok ini akhirnya berbalik arah 
untuk menjadi oposisi dari pemerintahan. Keberhasilan Houthi sebagai kelompok oposisi adalah ia sering melakukan serangan terhadap pemerintahan. Hasil serangan ini berupa dikuasainya wilayah-wilayah vital termasuk ibukota Yaman yaitu Sana'a. Houthi yang beraliran Syiah mendapat respon baik oleh negara-negara Timur Tengah seperti Iran dengan aliran yang sama. Iran menganggap Houthi adalah seorang kawan. Faktor inilah yang akhirnya membuat Houthi memiliki kekuatan yang cukup besar untuk melawan pemerintahan Yaman (Maulana, 2018:107).

Setelah diketahui bahwa Houthi mendapatkan dukungan kekuatan dari Iran, membuat Arab Saudi menafsirkan bahwa kerjasama ini merupakan suatu ancaman baginya. Mereka memandang ideologi yang dibawa Houthi dpat mengancam keberadaan ideology lain seperti Sunni yang dipakai oleh Arab Saudi, maka akhirnya Arab Saudi membuat suatu aliansi dengan berbagai negara seperti Qatar, Kuwait, Uni Emirat Arab, Yordania, Maroko, Mesir, dan Sudan untuk mengintervensi konflik yang ditimbulkan Houthi di Yaman.

Adapun alasan lain yang yang juga menjadi motivasi Arab Saudi mengintervensi Yaman, bukan semata-mata hanyalah persoalan ideologi, namun juga melihat letak geografis Yaman yang memiliki potensi pada bidang sumber daya dengan kadar tanah yang subur terlebih posisi dari adanya Bab-el-Mandebyang menjadikan Yaman sebagai incaran bagi negara-negara lain (Maulana, 2018:108).

Selain Arab Saudi yang memandang kemunculan Houthi adalah sebuah ancaman, hal ini juga dirasakan oleh Amerika Serikat dengan kekuatan Great Power melihat kemunculan Houthi juga mampu menyebabkan ancaman keamanan bagi masyarakat dunia. Amerika Serikat memiliki kekuatan lebih dari kelompok Houthi, yang mana seharusnya tidak sepadan dengan kekuatan suatu negara, kini mampu menyaingi hingga menyamai kekuatan kemiliteran negara. Amerika Serikat menempatkan dirinya dalam fenomena ini sebagai negara yang besar perlu adanya turun tangan dalam menyelesaikan konflik di Yaman. Hal ini s diperkuat ketika saat itu pemerintah Yaman sendiri yang meminta bantuan langsung kepada Amerika Serikat dalam menangani Houthi di Yaman. (Putri, 2018). Peristiwa ini menjadi sorotan dunia dimana banyak kepentingan khusus yang dimiliki kedua negara ini dalam mengintervensi konflik di Yaman dengan mengatasnamakan perdamaian. Dibuktikan dengan masuknya intervensi dari Arab Saudi dan Amerika Serikat untuk segera menyelesaikan konflik di Yaman. Namun, dari kedua negara ini memiliki kepentinganya masing-masing. 
Pemberontakan yang terjadi semakin memperparah kondisi negara dengan semakin banyaknya korban kekerasan yang terus terjadi terutama bagi masyarakat kaum lemah layaknya anak-anak dan perempuan. Setidaknya lebih dari 716 kasus pelanggaran HAM yang merujuk pada serangan fisik, kesewenangan, hingga penyiksaan yang dilakukan oleh beberapa aktor yang terlibat. Mengenai siapa yang bertanggung jawab penuh dalam kejadian ini adalah Houthi, militer Yaman yang dibantu oleh Arab Saudi dan Amerika Serikat.

Melalui aliansi yang mereka ciptakan dengan melakukan serangan udara dan darat dengan sasaran yang tidak tepat. Dampaknya berimbas pada tempat umum seperti sekolah dan rumah sakit dengan sedikitnya terbunuh 10.000 jiwa serta 7 juta orang sangat membutuhkan bantuan pangan (Rochmat, 2017). Dengan kekuatan yang dimilikinya Arab Saudi dan Amerika Serikat sudah mulai mengikut campuri segala permasalahan yang ada, konflik yang ditangani bukan semakin membaik namun semakin buruk dan sulit mencari titik temu.

Dari latar belakang yang dikemukakan penulis maka munculah sebuah asumsi dasar yang berfokus pada tindakan intervensi yang dilakukan Arab Saudi dan Amerika Serikat semakin meningkatkan tingkat pelanggaran HAM di Yaman. Terbukti pada tindakan agresif pada serangan yang justru meleset dan selalu masyarakat sipil menjadi korbannya. Jika tujuan awal mereka mengintervensi untuk perdamaian maka bisa dikatakan ini sebuah kesalahan. Arab Saudi dengan kepentingan aliran serta Amerika Serikat mengatasnamakan keamanan dunia, tetapi mereka tetap membawa kepentingan individu yang mampu menguntungkan negaranya sendiri.

Oleh karena itu penulis tertarik untuk menganalisa apa saja faktor-faktor yang melatarbelakangi adanya pelanggaran HAM di Yaman pada masa pemerintahan Ali Abdullah Saleh mengingat bahwa pada periode tersebut interval pelanggaran terhadap HAM di Yaman sangat intens atau banyak dibandingkan pada periode kepemimpinan setelahnya.

Periode Ali Abdullah Saleh menjadi periode terburuk dalam krisis kemanusiaan dikarenakan banyaknya peristiwa perebutan kota-kota penting di Yaman oleh Houthi dan pemerintah yang mengakibatkan korban jiwa lebih dari 10.000 jiwa hingga insiden digulingkannya masa pemerintah Ali Abdullah Saleh dengan adanya perjanjian The Gulf Cooperation Council (GCC) (Ghafur, 2015:124). Meskipun sudah digulingkan bukan berarti 
kasus pelanggaran HAM berakhir, pada masa Mansour Hadi juga mengalami pelanggaran HAM namun tidak seburuk masa sebelumnya

\subsection{Rumusan Masalah}

Mengamati kondisi konflik yang terjadi di Yaman serta pelanggaran HAM yang terusmenerus meningkat setelah adanya intervensi dari Arab Saudi dan Amerika Serikat, maka memunculkan perumusan masalah untuk penelitian ini "Apa saja faktor-faktor yang menyebabkan pelanggaran HAM di Yaman pada pemerintahan Ali Abdullah Saleh?"

\subsection{Metode Penelitian}

Metode penelitian yang digunakan oleh penulis dalam penelitian ini adalah dengan pendekatan kualitatif dengan jenis penelitian yang dipakai adalah deskriptif. Deskriptif disini menjelaskan mengenai isu yang dibahas dengan penjelasan yang lebih jelas dan rinci. Teknik pengumpulan data yaitu menggunakan data sekunder berasal dari penelitian terdahulu yang termuat dari artikel, jurnal, skripsi, dan situs berita di internet yang masih membahas isu dan penelitian yang sama.

\section{TINJAUAN PUSTAKA}

\subsection{Konsep Konflik}

Konflik secara bahasa berasal dari kata kerja Latin yaitu configure yang artinya memukul. Secara sosiologis diartikan sebagai suatu proses sosial antara dua orang atau lebih yang berusaha menyingkirkan pihak lain dengan cara menghancurkannya (Fiqri, 2019). Dapat didefinisikan yang disebut konflik merupakan akibat dari adanya keinginan yang berbeda antara satu dengan yang lain, sehingga salah satu atau keduanya saling terganggu (Wahyudi, n.d:3).

Berdasarkan tingkatanya (Irwandi \& Endah, 2017:28), konflik dibagi menjadi 3 jenis yaitu :

a. Konflik atau pertentangan pribadi, yaitu konflik yang terjadi antar individu yang memiliki pandangan yang berbeda. 
b. Konflik atau pertentangan rasial, yaitu konflik yang timbul karena adanya perbedaan ras. Misalnya konflik etnis.

c. Konflik atau pertentangan antara kelas-kelas sosial, yaitu konflik yang disebabkan perbedaan pandangan antar kelas sosial. Misalnya kaum borjouis yang memiliki banyak modal dengan kaum proletar yang menjadi buruh.

d. Konflik atau pertentangan politik, yaitu konflik yang terjadi dalam dunia perpolitikan akibat adanya kepentingan atau tujuan politis seseorang atau kelompok.

e. Konflik yang bersifat Internasional yaitu konflik yang terjadi karena perbedaan kepentingan yang berpengaruh pada kedaulatan Negara.

Penjelasan jenis konflik diatas mengaitkan dalam konflik Yaman termasuk ke dalam jenis konflik pertentangan politik, yaitu adanya kepentingan-kepentingan yang dilakukan pemerintah Yaman dalam menegakkan otoriternya, Houthi dengan kepentingan penegakkan keadilan, serta keterlibatan Amerika Serikat dan Arab Saudi yang memiliki tujuan lain daripada hanya misi perdamaian.

Keterkaitan konsep dengan isu penelitian kali ini dapat dilihat dari kemunculan konflik bermula yang dikarenakan adanya dua pandangan yang berbeda. Dari pihak pemerintah dengan kepemimpinan Saleh yang begitu otoriter dengan masyarakat sipil Yaman yang merasa tidak adanya ketidakadilan dalam pemerintahan Saleh. Perbedaan ini menjadi bentuk keterganggunya masyarakat dengan kebijakan Saleh yang diwujudkan dengan tindakan aksi demonstrasi. Aksi demontrasi yang berkelanjutan yang akhirnya melahirkan banyak oposisi dalam pemerintahan Saleh yang akhirnya membentuk gerakan melawan pemerintah yang disebut dengan Houthi.

\subsection{Konsep Hak Asasi Manusia}

Hak asasi manusia secara bahasa selalu berbeda-beda disetiap negara. Dalam bahasa asing, istilah hak asasi manusia dikenal dengan droit de l'home (Perancis), human right (Inggris) atau mensen rechten (Belanda) (Marsudi, 2001:83). Pengertian hak asasi manusia menurut Rover yaitu seorang ahli adalah hak hukum yang telah dimiliki oleh setiap orang sebagai manusia, hak tersebut dimiliki secara universal baik kaya maupun miskin, laki-laki maupun perempuan. Hak ini dapat dilanggar namun tidak dapat dihapuskan (Belajar Giat, 2020) . 
Beberapa unsur atau elemen yang mejadi inti dari adanya konsep HAM (Zakiya, 2017) ada 4 yaitu :

a. Universal, bersifat menyeluruh tanpa terkecuali.

b. Tetap, HAM akan selalu ada dan melekat pada diri manusia sebagaimana anugerah dari Tuhan.

c. Hakiki, hak yang sudah ada sejak lahir bahkan sejak amsih dalam kandungan.

d. Utuh, bahwa HAM tidak dapat dibagi antar sesame manusia.

Konsep ini dengan jelas mengartikan bahwa setiap manusia berhak untuk hidup aman dan tenang tanpa gangguan. Seperti yang kita bisa bayangkan kondisi di Yaman dengan krisis konflik yang begitu besar mampu merenggut setiap HAM yang dimiliki masyarakat disana. Dalih ini semakin dibuktikan bahwa memang sudah terlalu sering pelanggran HAM di Yaman dengan banyaknya korban pengeboman disetiap kota dengan ketidaktepatan sasaran. Para aktor yang sedang berkonflik tidak bisa meminimalisir adanya ketidaktepatan yang berdampak fatal. Nasib seseorang bisa buruk hanya karena ketidak akuratnya teknologi dan ambisi yang dilakukan oleh aktor yang berkonflik.

Dalam HAM terdapat beberapa masyarakat yang rentan terhadap ketimpangan HAM yaitu anak-anak dan perempuan. Namun, jumlah korban yang dari mereka juga cukup banyak. Melihat dari bangunan yangs sering menjadi sasaran adalah sekolah dan rumah sakit.

\subsection{Teori Hukum Humaniter}

Teori hukum humaniter atau disebut Humanitarian Law Applicable inArmed Conflictpada awalnya merupakan teori hukum yang membahas mengenai hukum perang (laws of war) yang kemudian berkembang menjadi hukum sengketa bersenjata (laws of arm conflict) (Wagiman, 2007). Tujuan dari adanya teori hukum humaniter ialah untuk mengatasi sebagian masalahmasalah yang menyangkut siapapun atau hak apapun dalam peperangan.

Bisa kita ketahui dalam terjadinya perang atau konflik pastinya akan banyak hal yang rentan untuk dilanggar oleh pihak manapun. Begitu juga dengan para aktor, masyarakat, ataupun kombantan (militer) juga perlu dilindungi. Teori huku humaniter telah menentukan perbedaan 
status dalam kondisi konflik antara combatan dengan civilian (Garner, 2004:262). Hukum kemanusiaan internasional memiliki salah satu prinsip yang relevan terhadap kondisi Yaman yaitu prinsip Humanitarian Intervention dimana dalam prinsip tersebut dibenarkan bahwa intervensi kemanusiaan dibenarkan menurut hukum internasional dalam Piagam PBB Bab VII, yaitu dimana dalam dunia internasional melalui DK PBB berhak melakukan adanya intervensi jika terjadi suatu pelanggaran HAM yang berat di suatu negara dalam kondisi dimana negara menadapatkan ancaman perdamaian serta keamanan internasional (Oktaviani dkk, 2018:67).

Namun, ada beberapa pengecualian yang dikemukakan oleh PBB bahwa tindakan intervensi ini memiliki tujuan ketika dalam suatu negara sudah memiliki kadar kedaruratan dalam perlindungan kemanusiaan serta kedaulatan negara akan terbatas. Dimana suatu negara dengan sengaja melakukan pelanggaran HAM terhadap masyarakat sipilnya sendiri. (Oktaviani dkk, 2018:68). Alhasil secara hukum perlu adanya intervensi dari negara lain atraupun organisasi lain untuk bisa meredakan atau menurunkan tingginya angka pelanggaran. Hukum ini justru disalah artikan oleh banyak negara dimana intervensi diperbolehkan oleh PBB akan tetapi dalam melakukan intervensi ditemukan adanya pelarangan dalam melakukan kekerasan, agresi senjata maupun militer sesuai dengan Pasal 2 ayat (4) adanya pelarangan negara-negara menggunakan agresi/kekerasan dalam menyelesaikan suatu sengketa.

Melihat kondisi konflik yang terjadi di Yaman begitu besar membuat jatuhnya banyak korban khususnya bagi masyarakat sipil yang menjadi korban kebiadaban para aktor yang berkonflik. Hal ini mencerminkan adanya ketidaksesuaian dalam prinsip hukum yang ada dimana negara yang mengintervensi Yaman justru mendominasi dalam melakukan agresi militer.

Teori hukum humaniter memiliki pembagian terhadap status masyarakat sipil dalam suatu konflik bersenjata berstatus civillian yang mana harus dilindungi. tertera pada Konvensi Jenewa 1949 dan Protokol Tambahan II yang berisi tentang perlindungan terhadap masyarakat sipil. Walaupun kita ketahui dalam perang atau konflik yang menjadi korban adalah kombatan (militer) maka dari itu masyarakat maka dari itu masyarakat sipil wajib dilindungi. Namun, jika masyarakat sipil ikut dalam perang dan mengangkat senjata maka hukum itu akan hilang (Wulandari \& Darmawan, n.d:3-5). Dalam hukum humaniter terdapat kelompok yang rentan yaitu anak-anak dan perempuan yang perlu mendapatkan hukum khusus dalam melindunginya yaitu terdapat pada Konvensi Jenewa 1949 dan Protokol Tambahan 1977 yang memberikan 
jaminan perlindungan terhadap perempuan dari kekerasan seksual dalam konflik (Hilda, 2010:105). Serta membentuk penerimaan kewajiban dalam Konvensi Jenewa IV yaitu The declaration on the protection of women and children in emergency yang berisi tentang kecaman penindassan terhadap perempuan dan anak-anak (Triana, 2009).

\section{HASIL DAN PEMBAHASAN}

\subsection{Munculnya Kelompok Pemberontak dan Strateginya dalam Menghadapi Pemerintah}

Konflik yang tengah terjadi di Yaman, tidak akan terhindar dari adanya suatu kelompok pemberontak dimana kelompok ini adalah kelompok oposisi yang melawan pemerintah Yaman. Kelompok pemberontak ini menjadi salah satu pemicu dari adanya konflik yang berkepanjangan di negara Yaman, kelompok ini disebut dengan Houthi.

Houthi memiliki suatu paham dalam islam yaitu Syiah Itsna Asyariyah atau kita bisa kenal dengan aliran Syiah 12 (Aksi ,2018). Houthi muncul dari sebuah desa kecil atau kota kecil Sha'dah yang terletak $240 \mathrm{Km}$ di utara Shan'a (Hadi, 2015). Di tempat ini banyak orang dari paham Syiah berkumpul dan mempelajari ajaran yang mereka yakini. Agenda mereka adalah membentuk kelompok persatuan pemuda yang disebut Ittihad Asy-Syahab untuk mengelkan kondisi sosial poitik dan budaya pada para pemuda Yaman.

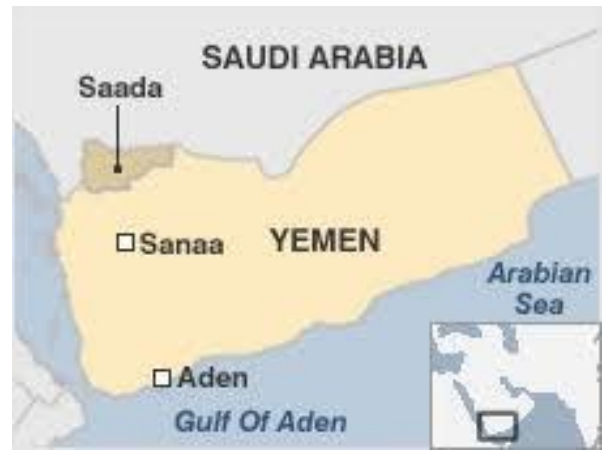

\section{Gambar 1. Peta dari Sa'dah}

(Sumber : Republik Eusosialis Tawon)

Setelah adanya penyatuan wilayah Yaman yang dibagi menjadi utara dan selatan pada tahun 1990, sistem demokrasi menuntut adanya partai politik serta parlemen. Pada saat itulah 
kelompok Ittihad Asy-Shahab mulai terjun dalam partai politik dan menjelma sebagai Perti AlHaq (Hizbul Haq) dalam menyambung aspirasi para kaum dari aliran Syiah Zaidiyah di Republik Yaman. Partai ini diketuai oleh seorang kader yang bernama Husein bin Badruddin Al-Houthi, anak dari Badruddin Al-Houthi. Husein merupakan salah satu anggota parlemen yang terkenal saat itu pada 1993-1997 dan 1997-2001.

Awal mula peristiwa pemberontakan terjadi pada tahun 2004 dimana kelompok Houthi yang dipimpin oleh Husein melakukan perlawanan terhadap pemerintah Yaman yang dianggap mendukung adanya ekspansi Amerika Serikat ke Irak. Tidak hanya itu, Houthi juga memprotes perlakuan penindasan dan diskriminatif Presiden Ali Abdullah Saleh dalam merealisasikan otonomi khusus di Yaman Utara. Akan tetapi pemerintah menyikapi dengan sikap represif dan menyatakan perang terbuka terhadap pemberontak Houthi. Pencarian yang dilakukan oleh pemerintah Yaman untuk bisa membasmi Houthi terus dilakukan. Pemerintah bahkan berhasil menyita persenjataan serta mengintruksikan untuk membunuh ketuanya.

Tidak lama dari intruksi itu Husein sang ketua kelompok berhasil dibunuh setelah Presiden Ali Abdullah Saleh mengirim pasukan ke Saada (RET, 2012). Namun, keberhasilan pemerintah ini tidak mengakhiri dari jalan Houthi untuk tetap eksis dalam melakukan pertempuran. Houthi bukan hanya suatu kelompok yang muncul dari adanya operasi tempur, akan tetapi melihat dari segi struktur, proses, dan nilai-nilainya sudah terbentuk secara organik di tempat atau lingkungan awal mereka berada (Jakti \& Jamil, 2015:5). Hal ini cukup pening bahwa Houthi mampu memobilisasi prinsip-prinsipnya yang telah dipelajari di tempat asal mereka.

Setelah ketua mereka wafat, kedudukannya diambil alih oleh Allamah Badruddin AlHouthi. Akan tetapi Allamah tidak lama menjabat menjadi ketua kelompok terkena penyakit yang akhirnya menewaskannya. Kedudukan selanjutnya diteruskan oleh puteranya yaitu Abdel Malik Al-Houthi. Melihat dari kedudukan pemimpin kelompok tidak serta merta memiliki focus wilayah yang sama. Lokasi geografis dari penempatannpara pemimpin Houthi beragam di seluruh konflik yang pernah diketahui. Hal ini disebut Local Area Leaders (LAL) atau daerah control yang dikehendaki para pemimpin (Jakti \& Jamil, 2015:6). Model ini juga diperkirakan sangat efektif dalam pelaksanaan operasi tempur, dimana para komandan berada di daaerah terpencil dan mengatur pertukaran informasi antar komando secara bersamaan. 
Penyebaran pada lembaga sosial masyarakat juga dapat meningkatkan keefektifan pola strategi yang dibuat Houthi lebih mudah dan terkoordinir.Penggunaan senjata juga sudah mulai dibendung dari pihak pemerintah untuk mampu mempersempit kekuatan Houthi.Pemerintah bekerjasama dengan Pemerintah Arab Saudi di perbatasan dan pengembangan Yaman Coast Guard dengan Amerika Serikat bertujuan untuk memperketat persenjataan melalui pedagang tradisional maupun internasional (Jakti \& Jamil, 2015:7).

Keterlibatan Iran sebagai negara penyokong kelompok Houthi juga beredar pada tahun 2004 saat masa Presiden Ali Abdullah Saleh. Bantuan finansial dan pelatihan militer diduga didapat dari pemerintah Iran. Bukti ini diperkuat ketika adanya fakta bahwa senjata yang digunakan oleh kelompok Houthi memiliki kesamaan dengan senjata yang digunakan oleh militer Iran (Jakti \& Jamil, 2015:8). Ali Abdullah Saleh mengklaim keterlibatan Iran semakin terbukti lagi ketika pemerintah Yaman mulai melakukan penyitaan barang bukti senjata yang dirampas dari sebuah gudang senjata Houthi memperlihatkan bahwa senjata itu merupakan rakitan dari Iran. Iran merupakan kelompok dari adanya Houthi dengan adanya dukungan penuh terhadap perluasan paham Syiah.

\subsection{Intervensi Arab Saudi dan Amerika Serikat}

Pergeseran adanya suatu kebutuhan dan kepentingan dalam masyarakat internasioal telah menimbulkan adanya hubungan timbal balik antar aktor atau negara baik berupa hubungan diplomatik, politik, kerjasama ekonomi, sosial dan budaya, militer bahkan dalam kerjasama persahabatan atau aliansi. Ketika akhirnya suatu kepentingan ini menghasilkan suatu keuntungan bagi pihak yang terlibat secara adil, maka hubungan yang terjalin akan sesuai dengan tujuan mereka. Akan tetapi tidak semua hubungan dapat berjalan sesuai apa yang telah direncanakan, dimana akan ada suatu kondisi bagi phak yang bekerjasama tidak mampu mengakomodir semua keinginan para pihak. Perbedaan inilah yang akan mengakibatkan terjadinya pertentangan yang pada ujungnya mampu memicu sebuah konflik.

Melihat kondisi konflik Yaman yang memiliki tingkat kerumitan yang cukup tinggi membuat adanya keinginan bagi para aktor internasional atau pihak asing untuk berkeinginan terlibat dalam konflik. Kondisi ini bisa kita sebut dengan intervensi. Salah satu aktor negara internasional yang terlibat adalah Arab Saudi. Hal ini dilakukan Arab Saudi karena adanya 
keinginan untuk bekerjasama dengan pemerintah Yaman menurunkan tingkat konflik yang ada sehingga semakin besarnya kemungkinan adanya suatu perdamaian.

Arab Saudi merupakan salah satu negara yang terlibat konflik internal Yaman, terlebih dia berada sangat dekat dengan Yaman. Terlebih lagi bahwa Arab Saudi memiliki dominasi rakyatnya yang menganut ajaran Sunni, sedangkan hal ini sangat bertolak belakang dengan Yaman yang beraliran Syiah. Salah satu alasan yang membuat respon masyarakat Yaman tidak segan dengan adanya keterlibatan Arab Saudi yaitu adanya perbedaan paham atau ajaran, selanjutnya penolakan semakin kuat dilakukan masyarakat Yaman Ketika dimana keberadaan Arab Saudi yang seolah-oleh mendukung bahkan melindungi pemimpinya yaitu Ali Abdullah Saleh atas tindakannya. Penolakan inilah yang akhirnya pecah dalam suatu demonstrasi.

Tindakan Arab Saudi semakin membuat kekacauan ketika mereka mulai mengirimkan bantuan militer berupa senjata dan tantara bayaran untuk melawan pergolakan anti pemerintah pada tahun 2011. Tidak hanya itu, bantuan Kembali dilakukan ketika dalam aksi demonstrasi Ali Abdullah Saleh terkena serangan, pihak medis Arab Saudi segera mengirimkan bantuan dengan akses jet pribadi. Bantuan terus mengalir hingga pada saat adanya kekacauan yang tidak dapat dibendung lagi dimana Arab Saudi meminta untuk melakukan adanya transisi kekuasaan (Tristiana \& Muharjono, 2013:26). Arab Saudi mengusulkan untuk melakukan transisi kekuasaan di kota Sana'a. Transisini ini seakin didukung dan mendapat respon baik bagi negaranegara di Teluk Arab dan Dewan Keamanan PBB yang akhirnya menghasilkan suatu proposal. Proposal ini berisikan bahwa Ali Abdullah Saleh harus segera menyerahkan kekuasaannya kepada wakilnya yaitu Mansor Hadi, dengan imbalan Ali Abdullah Saleh akan mendapat kekebalan hukum (Al Qadhi, 2011).

Sikap ini sungguh tidak adil bagi masyarakat dimana sesuai hukum humaniter internasional yang ada, prinsip non intervensi sudah ditetapkan dalam piagam PBB Pasal 2 ayat 7 yang intinya adanya larangan bagi suatu negara untuk mencampuri urusan dalam negeri dalam bentuk apapun. Namun, biasanya intervensi ini mendapatkan persetujuan yang sah dari pihak Yaman, yaitu presiden Ali Abdullah Saleh yang memiliki hubungan dekat dengan pihak Arab Saudi. Analisis ini memfokuskan pada aktor diktator Ali Abdullah Saleh yang menjadi pelaku adanya perijinan terhadap konflik internalnya sendiri yang pada akhirnya keuntungan hanya diterima oleh pihaknya sendiri. 
Intervensi Arab Saudi yang bahkan memberikan bantuan langsung dibidang militer dan persenjataan bagi para oposisi Yaman yang sudah tidak sesuai dengan pasal 2 ayat 4 Piagam PBB yang dimana dilakukan dengan cara kekerasan. Hal ini akan berakibat pada jatuhnya korban dai masyarakat sipil maupun para tantara yang seharusya dilindungi. Terkait dengan bagaimana dampaknya bagi masyarakat sipil yang telah diatur alam Konvensi Jenewa IV 1949 dan Protokol Tambahan II yang berisikan khusus menangani perlindungan masyarakat sipil dalam konflik bersenjata (Dini dkk, 2017:3).

Kondisi pergolakan terhadap para oposisi masyarakat sipil (Houthi) dan tantara pemerintah Yaman yang dibantu Arab Saudi menyita perhatian dunia terutama bagi Amerika Serikat. Kekacauan yang terjadi di Yaman dipandang oleh Amerika Serikat sebagai isu terorisme. Amerika Serikat mendukung koalisi Arab Saudi dengan memberikan dukungan berupa bantuan intelijen untuk mampu memaksimalkan serangan udara dalam keperluan logistik dan senjata dalam membasmi Houthi atau para oposisi. Amerika Serikat berasumsi juga bahwa kelompok Houthi juga akan memiliki relasi keterkaitan dengan kelompok pemerontak terorisme yang lain seperti Al Qaeda dan ISIS. Berulang-ulang kali pengeboman bunuh diri terjadi yang menewaskan 130 korban jiwa yang mana ini bukan hanya rencana pribadi Houthi sendiri akan tetapi ini strategi para terorisme. Amerika Serikat menyatakan bahwa ia akan segera menghentikan konflik Yaman dengan berfokus pada penghancuran Al Qaeda.

Hal yang paling mengejutkan bahwa para aktor negara yang mengintervensi Yaman justru memiliki agenda lain selain untuk mengakhiri konflik. Amerika Serikat pernah melakukan pembayaran kepada beberapa komandan Al Qaeda untuk meninggalkan daerah-daerah tertentu sehingga mampu memperoleh senjata, peralatan serta uang jarahan (Basuki dkk, 2019:15). Dari pihak Arab Saudi juga ditemukan pernah merekrut anggota Al Qaeda untuk masuk dan bergabung dalam pasukannya dan bahkan hal ini disadari oleh kedua negara. Pengungkapan tersebut sangat kontradiktif terutama Amerika Serikat yang hanya bertujuan untuk menghancurkan Al Qaeda, bahkan misi ini lebih besar dari adanya perang saudara di Yaman.

Alasan lain yang menjadi faktor pendorong Arab Saudi dan Amerika Serikat melakukan intervensi adalah masalah geografis. Yaman memiliki letak geografis yang sangat strategis dimana posisinya yang langsung berbatasan dengan Arab Saudi di sebelah utara dan Laut Merah serta pesisir Laut Aden yang begitu pentng dalam perdagangan internasional. Posisinya yang 
begitu dekat dengan Arab Saudi juga menjadikan alasan negara tersebut ikut andil untuk mampu menjaga kondisi status quo Yaman terhadap pemerintahan pro-Arab Saudi. Dukungan Amerika Serikat dalam koalisi Arab kini memiliki tujuan untuk mampu mengendalikan penguasaan melalui intervensi di negara Timur Tengah dari adanya pengaruh Iran.

\subsection{Peningkatan Pelanggaran HAM Pasca Adanya Intervensi}

Koalisi atau intervensi yang dilakukan Arab Saudi dan Amerika Serikat terhadap konflik di Yaman mampu membuat peristiwa pelanggaran HAM terus meningkat. Sebelum adanya intervensi kondisi Yaman memang sudah sangat kacau dimana pemberontakan terus terjadi antar kelompok Houthi dan Pemerintah. Hal inilah yang menjadi salah satu faktor yang menjadikan tindakan pelanggaran HAM terjadi dikarenakan adanya suatu kelompok oposisi yang akhirnya menjadi pihak lawan dari pemerintah Yaman saat pemerintahan Ali Abdullah Saleh. Houthi merupakan alasan utama adanya ikut campur tangan atau intervensi dari negara lain seperti Arab Saudi dan Amerika Serikat. Maka dari itu bisa dianalogikan bagaimana jika ada campur tangan negara lain dalam memperkeruh kondisi dan bisa kita ketahui Arab Saudi dan Amerika Serikat merupakan negara besar dan pastinya memiliki perlengkapan persenjatan super canggih yang mampu melakukan penumpasan musuh secara instan.

Dalam kasusnya yang terjadi Arab Saudi tercatat sering melakukan Tindakan peledakan atau pengeboman yang digunakan dari berbagai persenjataan seperti roket dan mortir. Senjata ini bertanggung jawab atas kematian 23\% masyarakat sipil dari 1.037 dan luka-luka dari penggunaan artileri,mortir, dan roket. Secara total, terdapat 1.104 kematian dan cedera yang tercatat yang berarti terdaat $94 \%$ dari catatan kematian dan cedera berasal dari senjata peledak. Senajata ini juga diluncurkan dengan bebas oleh para pasukan militer maupu kelompok oposisi ke daerah-daerah berpenduduk.

Peluncuran serangan dengan melakukan pengeboman dan penembakan sering terjadi di kota - kota besar seperti kota Aden dan Taizz. Masyarakat sipil menyaksikan secara langsung bahwa adanya hujan roket yang kerap menghiasi langit kota Aden dan Taizz. Senjata roket yang digunakan berjenis "Katyusha" dimana sistem roket ini berkekuatan besar dan memiliki durasi waktu yang cukup singkat. Kurang lebih terdapat 32 masyarakat sipil tewas dan 67 lainnya lukaluka akibat senjata tersebut. Tidak hanya terhenti pada aksi darat saja, serangan juga dilakukan 
Arab Saudi dan Amerika Serikat di wialyah udara. Senjata peledak yang diguakan melalui pesawat terbang berasal dari rudal dan bom. Tercatat total 3.287 kematian yang berasal $82 \%$ berasal dari masyarakat sipil (Merliani, 2019:42). Serangan udara yang dilakukan banyak yang menyasar pada tempat-tempat umu seperti sekolah dan rumah sakit dimana banyak anak-anak dan peremuan yang menjadi korban kebiadaban perang.

Kondisi yang begitu memprihatinkan yang dialami oleh masyarakat sipil Yaman menunjukkan bahwa perlunya suatu bantuan kemanusiaan untuk mampu menopang kerugian dan keperluan logistik yang susah untuk dibutuhi. Banyak sekali komunitas internasioal yang memaparkan bahwa kondisi Yaman saat ini sangat beresiko terhadap adanya kelaparan (Matamata Politik, 2020). Bahkan hamper 30 juta penduduknya beresiko mengalami kematian pada level kelaparan yang kronis.

Kedaruratan terhadap adanya hak asasi manusia yang terjadi pada konflik Yaman tergambar dari adanya efek dari adanya sebuah intevensi suatu negara. Efek yang ditimbulkan berupa korban jiwa yang pada dasarnya didominasi oleh masyarakat sipil yang tidak bersalah. Banyaknya korban tidak membuat pergolakan perang semakin menurun, namun para pihak yang bersengketa bahkan mengesampingkan nilai-nilai kemanusiaan pada masyarakatnya sendiri.

\section{KESIMPULAN}

Pemerintah merupakan aktor yang sangat besar pengaruhnya dalam berbagai bidang. Termasuk dalam perpolitikan yang terjadi di Yaman dimana Ali Abdullah Saleh sebagai pemimpin saat itu menerapkan sistem dimana setiap tindakan dan keputusan diambil berdasarkan kehendak Pemimpin atau disebut diktator. Hal inilah yang menimbulkan kontra dari pihak masyarakat sipil yang dibuktikan dari adanya sebuah perlawanan atau oposisi. Salah satu oposisi yang menentang pemerintah Yaman adalah kelompok Houthi. Kelompok ini memiliki tujuan untuk menurunkan Ali Abdullah Saleh selaku Presiden Yaman yang melakukan kesewenangan di masa kepemimpinanny

Faktor-faktor penyebab terjadinya pelanggaran HAM diawali adanya kelompok Houthi yang memacu terjadinya angka konflik pihak lawan dari Ali Abdullah Saleh. Ali Abdullah Saleh mengklaim bahwa kelompok ini mampu memperburuk kondisi Yaman dan menetapkan untuk 
membasmi kelompok pemberontak ini. Fenomena ini akhirnya menjadi perhatian utama bagi Arab Saudi sebagai negara tetangga yang melihat kelompok Houthi mampu membahayakan keamanan karena membawa paham syiah yang berbeda dengannya. Tidak hanya itu, sebagai negara Great Power yaitu Amerika Serikat ikut serta dalam mendukung koalisi Arab dengan tujuan bahwa Houthi adalah sebuah kelompok teroris internasional.

Bantuan yang mereka berikan kepada Yaman membuat kondisi semakin buruk setelah pecahnya pergolakan antar pihak yang sedang berkonflik, hal ini menyebabkan banyak korban jiwa sebagai bukti adanya pelanggaran HAM di Yaman. Hal ini dikarenakan Arab Saudi dan Amerika Serikat memberikan banyak bantuan militer berupa persenjataan dari serangan udara, darat, maupun laut. Padahal sudah dijelaskan dalam hukum humaniter internasional sebagai hukum perang yang mampu mengurangi dampak buruk dalam medan konflik untuk melindungi para masyarakat sipil yang tidak bersalah. Intervensi dalam hukum dunia tidak diijinkan dalam bentuk apapun apalagi dalam intervensi milter. Bisa dikatakan kedua negara ini telah melanggar beberapa hukum dunia serta tidak langsung melakukan tindkaan pelanggaran HAM berat.

Jika kita lihat mekanisme mereka dalam membawa tujuan awal untuk perdamaian sangat tidak tercermin, terlihat dari tindakan mereka yang selalu menyerang daerah-daerah pemukiman padat penduduk yang dipenuhi banyak fasilotas umum seperti rumah sakit dan sekolah. Korban yang jatuh tidka lain dan bukan pastinya dari masyarakat sipil yang tidak berdosa. Aturan hukum humaniter tertera dengan jelas tindkaan itu telah melanggar Konvensi Jenewa 1949 yang menjelaskan adanya perlindungan terhadap masyarakat sipil dalam medan konflik. Banyaknya korban tidka merubah kebijakan apapun dari pihak pemberontak oposisi maupun Arab Saudi dan Amerika Serikat untuk mengungarngi jatuhnya korban lagi. Keinginan lain atau agenda lain yang dibawa bagi negara- negara besar seperti Arab Saudi dan Amerika Serikat adalah tidak untuk mnghentikan konflik perang saudara, namun terlebih dengan tujuan untuk ingin menguasai wilayah Timur tengah terutama Yaman yang memiliki letak geografis yang strategis dalam perdagangan internasional. 


\section{DAFTAR PUSTAKA}

Al Qadhi, M. (2011, April 12). Deadlock in Yemen over Gulf Cooperation Council peace plan. Retrieved from The National News: https://www.thenationalnews.com/world/mena/deadlock-in-yemen-over-gulfcooperation-council-peace-plan-1.607499

Aljazeera. (2015).UN says ex-Yemen president Saleh stole up to $\$ 60 \mathrm{bn}$. (2015, Februari 25). Retrieved from ALJAZEERA: https://www.aljazeera.com/amp/news/2015/2/25/un-saysex-yemen-president-saleh-stole-up-to-60bn

Basuki, A. R., dkk. (2019). Perang Saudara di Yaman: Analisis Kepentingan Negara Interventif dan Prospek Resolusi Konflik. Jurnal Ilmu Politik dan Komunikasi Volume IX No. 1, 510.

Belajar Giat. (2010).Pengertian HAM (Hak Asasi Manusia). (2020, Oktober 16). Retrieved from belajargiat: https://belajargiat.id/ham/

Dini, R. J., dkk. (2017). Tinjauan Yuridis Intervensi Militer Koalisi Saudi Arabia dalam Konflik Bersenjata di Yaman. 3.

Fiqri, M. (n.d.). Konsep Dasar Konflik. Retrieved from https://www.academia.edu/37058009/KONSEP_DASAR_KONFLIK

Garner, B. A. (2004). Blac's Law Dictionary. 262.

Ghafur, M. F. (2015). Problematika Kekuatan Politik Islam Diyaman, Suryah, dan Aljazair. Jurnal Penelitian Politik, 127.

Hadi, Nurfitri. (2015). Siapakah Pemberontak Houthi? (n.d.). Retrieved from Kisah Muslim: https://kisahmuslim.com/4969-siapakah-pemberontak-houthi.html

Hilda. (2010). Perlindungan Hukum Humaniter terhadap Perempuan dari Kekerasan Seksual dalam Sengketa Bersenjata. Vol XII No 2, 105.

Irwandi, \& Endah, R. C. (2017). Analisis Konflik Antara Mayarakat, Pemerintah, dan Swasta (Studi Kasus di Dusun Sungai Samak, Desa Sungai Samak, Kecamatan Badau, Kabupaten Belitung). Jispo Vol. 7 NO. 2, 28.

Jakti, G. P., \& Jamil, A. (2015). Upaya Pemerintah Ali Abdullah Saleh Menyelesaikan Konflik dengan Pemberontak Houthi. 5.

Jediza, F. (2017). Kondisi Umum dan Pemicu yang Menyebabkan Terjadinya Konflik Internal di Yaman. Bandung: Universitas Katolik Parahyangan.

Mata-mata Politik. (2020). Yaman: ' Pelanggaran yang Tak Ditngani Berisiko Jadi Kejahatan Perang. (2020, Desember 6). Retrieved from Matamata Politik: https://www.matamatapolitik.com/yaman-pelanggaran-tidak-diperiksa-bisa-jadikejahatan-perang/\# 
Marsudi, S. A. (2001). Pancasila dan UUD 45 dalam Paradigma Reformasi. Jakarta: PT Raja Grafindo Persada.

Maulana, M. S. (2018). Persaingan Kekuatan Sudi Arabia (Sunni) dan Iran (Syiah) pada Kasus Konflik Kontemporer (Suriah dan Yaman). Jurnal Gama Societa Vol. 2 No. 2, 106.

Merliani, L. (2019). Intervensi Arab Saudi dalam Konflik di Yaman dan Implikasinya Terhadap Humanitarian Crisis. 26.

Oktaviani, Rury, Febriana, \& Setyo. (2018). Penerapan Prinsip Humanitarian Intervention Sebagai Cara Penyelesaian Konflik Bersenjata Internasional Dikaitkan Dengan Kedaulatan Nnegara. SELISIK-Volume 4 Nomor 7, 67-68.

Putri, T. Y. (n.d.). Keterlibatan Amerika Serikat-Arab Saudi Pada Konflik Yaman dalam Upaya Pembendungan Pengaruh Iran di Yaman.

RET. (2012). Houthi, Kelompok Pemberontak dari Pelosok Utara Yaman. (2012, Maret 26). Retrieved from RET: https:/www.re-tawon.com/2012/03/al-houthi-kelompokpemberontak-dari.html

Rochmat, Muchlishon. (2017).Konflik Yaman Lahirkan Ratusan Kasus Pelanggaran HAM. (2017, November 21). Retrieved from NU ONLINE: https://www.nu.or.id/post/read/83428/konflik-yaman-lahirkan-ratusan-kasuspelanggaran-ham

Triana, N. (2009). Perlindungan Perempuan dan Anak Ketika Perang dalam Hukum Humaniter Internasional.

Tristiana, V., \& Muharjono. (2013). Dukungan Arab Saudi Terhadap Pemerintah Ali Abdullah Saleh dalam Revolusi Rakyat Yaman. Volume 17 No. 2, 26-30.

Wagiman, W. (2007). Hukum Humaniter dan Hak Asasi Manusia. Jakarta: Lembaga Studi dan Advokasi Masyarakat.

Wahyudi, A. (n.d.). Konflik, Konsep Teori dan Permasalahan. 3.

Wulandari, P. P., \& Darmawan, N. K. (n.d.). Perlindungan Hukum terhadap Warga Sipil dalam Konflik Bersenjata ( Non-Internasional) Libya Ditinjau dari Perseptif Hukum Humaniter Internasional. 3-5.

Zakiya, R. (n.d.). Pengertian HAM (LENGKAP): Definisi Para Ahli, Ciri-ciri dan Contohnya. Retrieved from Saintif: https://saintif.com/pengertian-ham/amp/ 